\title{
NOTE
}

\section{Huffmanela sp. (Nematoda: Trichosomoididae) muscular parasite from Trisopterus luscus captured off the Portuguese coast}

\author{
Alexandra Esteves ${ }^{1, *}$, Fernanda Seixas ${ }^{1}$, Susana Carvalho ${ }^{2}$, Nuno Nazário ${ }^{3}$, \\ Miguel Mendes ${ }^{3}$, Conceição Martins ${ }^{1}$ \\ ${ }^{1}$ Centre of Studies in Animal and Veterinary Science (CECAV), University of Trás-os Montes e Alto Douro (UTAD), \\ Apartado 1013, 5001-801, Vila Real, Portugal \\ ${ }^{2}$ Veterinary Medicine, University of Trás-os Montes e Alto Douro (UTAD), 5001-801, Vila Real, Portugal \\ ${ }^{3}$ Direcção Geral de Veterinária, Ministério da Agricultura, do Desenvolvimento Rural e Pescas, Largo da Academia Nacional \\ das Belas artes, no. 2, 1249-105, Lisbon, Portugal
}

\begin{abstract}
Four samples of Trisopterus luscus exhibiting unusual black spots on their musculature were obtained from catches made on different days and were rejected as unsuitable for consumption. Bipolar eggs somewhat resembling those of the nematode genus Huffmanela (Nematoda: Trichosomoididae) were identified as the cause of these black spots. Microscopic analysis revealed the presence of dark-shelled trichinelloid embryonated eggs dispersed throughout the muscle tissue, 73 to 94 $\times 40$ to $59 \mu \mathrm{m}$ in size, with large polar plugs 14 to $22 \mu \mathrm{m}$ wide. However, the morphology and distribution of the observed eggs were not compatible with any previously described Huffmanela species. Intracellular nematodes were also observed in muscle cells. In 2 samples, sectioned nematode specimens were observed in other locations as well: the lymphatic vessel of intestine submucosa and the dermal lymphatic vessel. This could be due to nematode migration inside the infected fish. The presumed identification of Huffmanela sp. in a new host (Trisopterus luscus), and in a new location (Atlantic Ocean) supports the belief that these parasites could be widely distributed, particularly in marine fishes. In view of these factors, together with the observed egg morphology, it is possible that these specimens represent a new, unidentified Huffmanela species.
\end{abstract}

KEY WORDS: Huffmanela · Trisopterus luscus $\cdot$ Portuguese coast · Black spots · Nematode Resale or republication not permitted without written consent of the publisher

\section{INTRODUCTION}

The teleost fish Trisopterus luscus Linnaeus (Gadiformes: Gadidae) is a benthopelagic species native of the eastern Atlantic Ocean. It can be found anywhere from the British Isles to the African coast and coastal islands, between $62^{\circ} \mathrm{N}$ to $25^{\circ} \mathrm{N}$ and $19^{\circ} \mathrm{W}$ to $16^{\circ} \mathrm{E}$; it is present at depths between 30 and $100 \mathrm{~m}$ (Svetovidov 1986). This fish species is very popular amongst Portuguese consumers.

Veterinary inspectors working at the Fish First Sales Services (fish auction) on the Portuguese coast have described the presence of unusual black spots on the musculature of these teleost species as a common cause for rejecting Trisopterus luscus as unfit for con- sumption. Fish exhibiting muscle with black spots are classified as black fish and are rejected due to their repugnant appearance. The presence of eggs of Huffmanela Moravec, 1987 (Nematoda: Trichosomoididae) has been given as the cause of the black spots and was previously described by Mendes (2006).

The appearance of Huffmanela eggs in human stools has already been reported (Schouten et al. 1968 cited in Moravec et al. 1998, Gállego et al. 1993), apparently as a result of prior consumption of infected fish. Although these parasites are seemingly unimportant from a public health point of view, the presence of egg masses in fish muscle causes commercial problems due to their unsightly appearance. At this time, the biology of Huffmanela spp. remains unknown (Moravec \& Garibaldi 2000). 
The aims of the present study were to (1) provide a microscopic description of the altered fish muscle tissue, (2) confirm the presumptive diagnosis, and (3) contribute to a better understanding of the poorly known distribution and biology of Huffmanela spp.

\section{MATERIALS AND METHODS}

Four samples of Trisopterus luscus exhibiting unusual black spots were obtained from catches made on different days; these fish were rejected as unfit for consumption at the Fish First Sales Services (fish auction) in Figueira da Foz (the fish were caught offshore near Figueira da Foz). The fish samples were fixed in $10 \%$ formalin and submitted to post mortem examination at the histopathology laboratory of the University of Trás-os-Montes e Alto Douro. Tissue samples were processed for light microscopy in accordance with standard methods, sectioned at $2 \mu \mathrm{m}$ and stained with haematoxylin \& eosin (H\&E).

In the absence of fresh samples, the fixed fish muscle was submitted to an artificial digestion and muscle scraping, and then to imprint techniques to allow egg observation. In the imprint techniques, tissues and eggs obtained from scraping were transferred to a microscope slide and observed through an optical microscope. In the digestion technique, a $1 \mathrm{~g}$ muscle sample was digested at $37^{\circ} \mathrm{C}$ for $60 \mathrm{~min}$ in a $0.6 \%$ pepsin-HCl solution as in Park et al. (2004), and eggs were preserved in $70 \%$ ethanol. In the scraping technique, tissue and eggs were observed in lactophenol. All observations were performed using a compound microscope (Nikon Eclipse E600) equipped with a digital camera (Nikon DXM 1200). Sixty-three eggs were measured. All measurements were made in micrometers and are given as means $\pm \mathrm{SD}$.

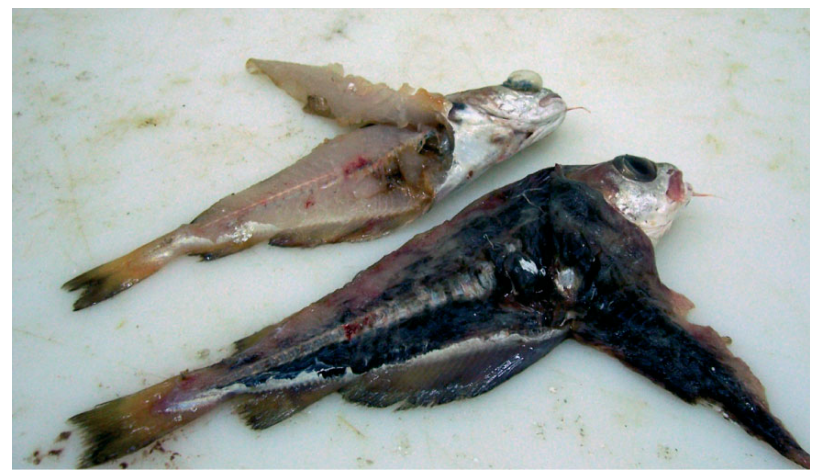

Fig. 1. Trisopterus luscus. Normal specimen (top); specimen exhibiting unusual black discoloration (bottom)

\section{RESULTS}

Macroscopically, all 4 fish analysed exhibited unusual black spots on the musculature that were easily observed through the skin (Fig. 1). The gill arches, skin and internal organs showed no macroscopic abnormalities. No adult nematodes were observed in the fish in the macroscopic examination.

Microscopic analysis revealed the presence of darkshelled trichinelloid embryonated eggs dispersed throughout the muscle tissue. The eggs, which were dark brown and oval or barrel-shaped, had a distinct light-coloured plug at each pole and contained larvae at various stages of maturity (Fig. 2). The muscle

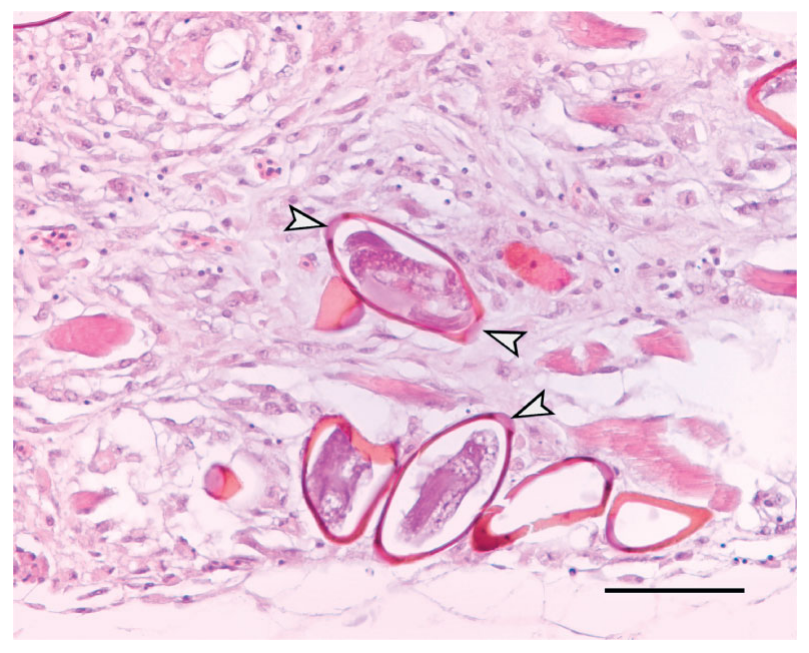

Fig. 2. Trisopterus luscus. Muscle tissue with trichinelloid embryonated eggs. Open arrowheads: polar plugs. H\&E staining; scale bar $=60 \mu \mathrm{m}$

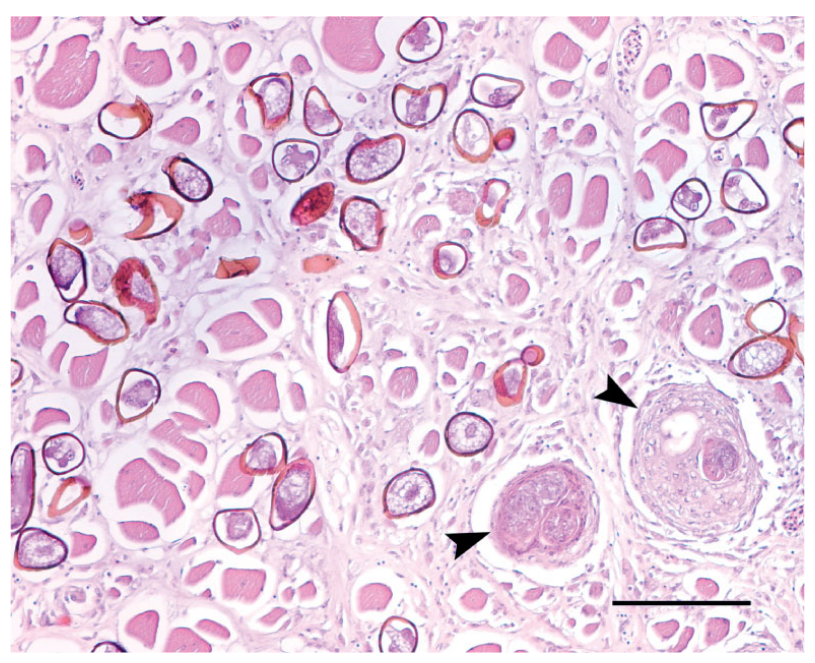

Fig. 3. Trisopterus luscus. Muscle tissue showing embryonated eggs in various maturation stages and small granulomas (arrowheads). H\&E staining; scale bar $=120 \mu \mathrm{m}$ 
exhibited myodegeneration, necrosis, calcification and small parasitic granulomas (Fig. 3). More heavily parasitized fish showed diffuse histiocytic infiltration and fibrosis. The location of eggs was sometimes intracellular, more frequently extracellular and also in granulomas. Occasionally, nematode specimens of an uncertain developmental stage (larvae or adults) could be observed inside the muscle cells (Fig. 4). The fish's skin, intestinal serosa and swim bladder exhibited no abnormalities. In 2 samples, sectioned nematode specimens were observed in different locations: the dermal lymphatic vessel and lymphatic vessel of intestine submucosa (Figs. 5 \& 6).

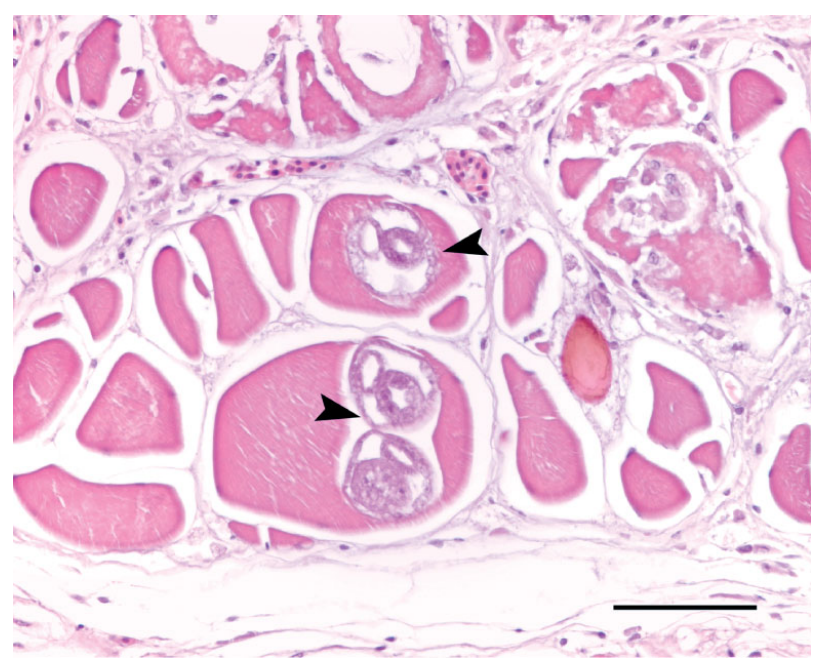

Fig. 4. Nematode specimens of an uncertain developmental stage (black arrowheads) inside Trisopterus luscus muscle cells. H\&E staining; scale bar $=60 \mu \mathrm{m}$

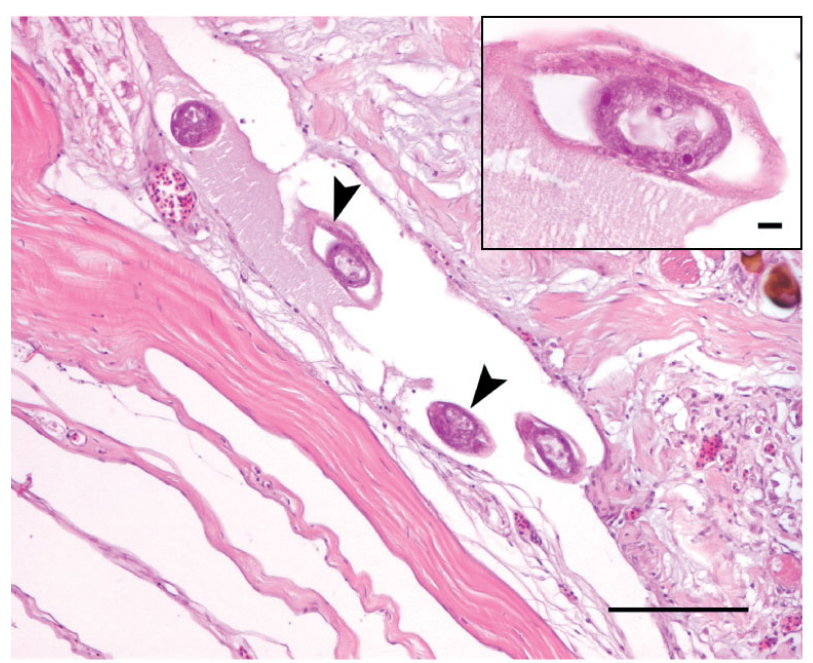

Fig. 5. Sectioned nematode specimens (black arrowheads) in a Trisopterus luscus dermal lymphatic vessel, with an enlarged view (inset). H\&E staining; scale bars $=120$ and $10 \mu \mathrm{m}$ (inset)

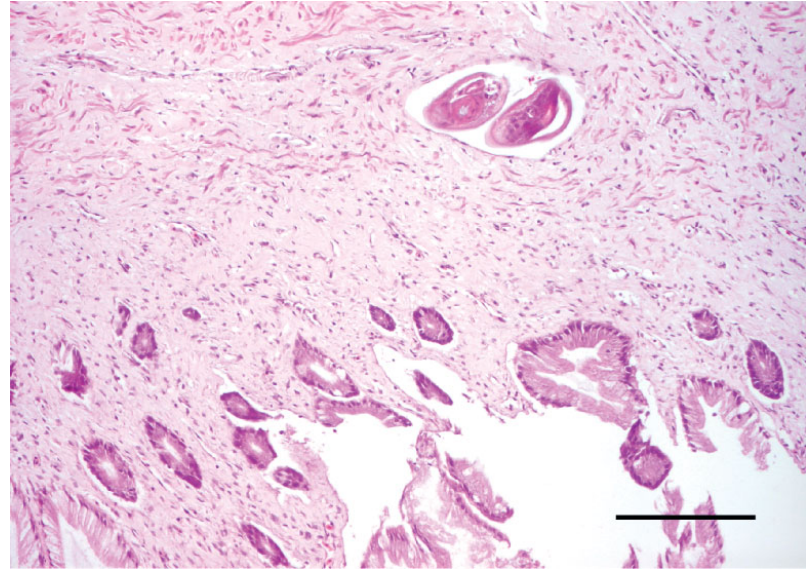

Fig. 6. Sectioned nematode species in a Trisopterus luscus lymphatic vessel of the intestine submucosa. H\&E staining; scale bar $=120 \mu \mathrm{m}$

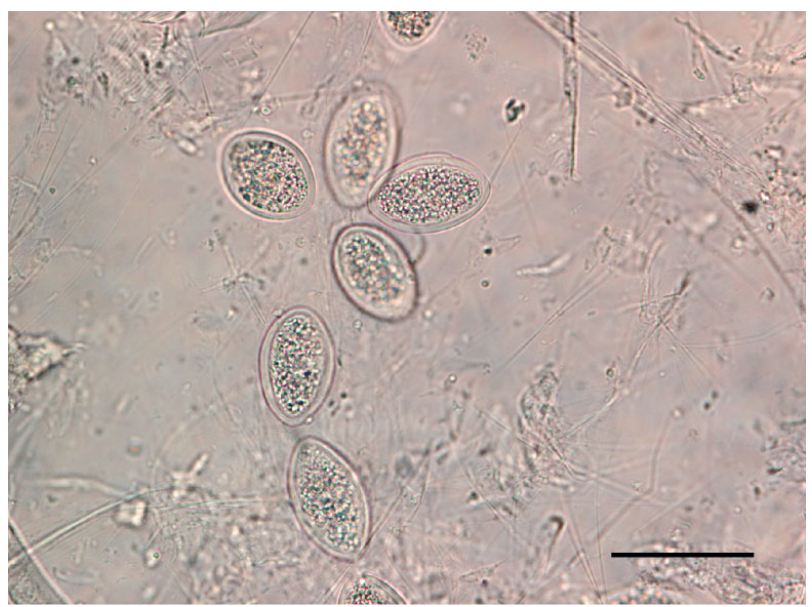

Fig. 7. Small, oval, pale eggs. Scale bar $=60 \mu \mathrm{m}$

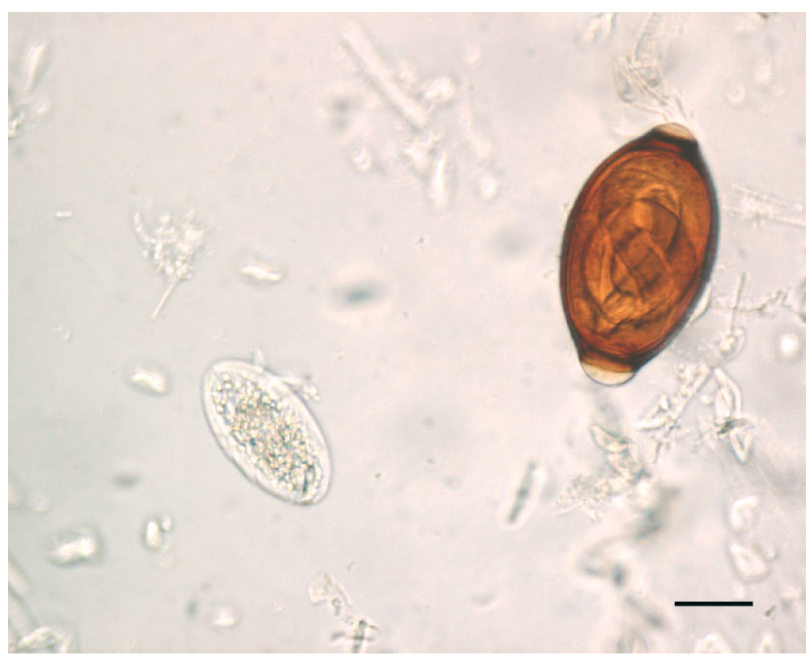

Fig. 8. Small, oval, pale egg and dark brown embryonated egg with larvae. Scale bar $=20 \mu \mathrm{m}$ 


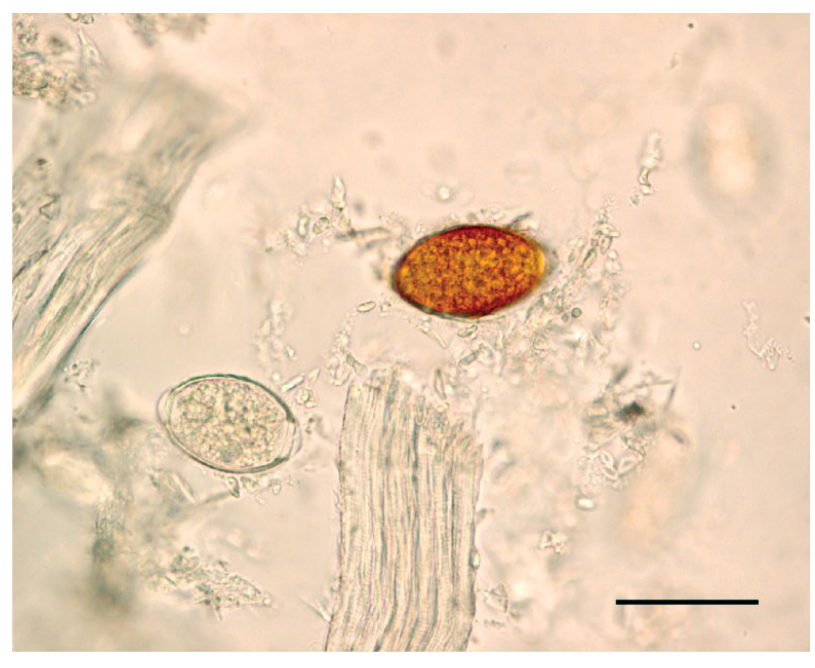

Fig. 9. Pale and embryonated (morula) egg with protruding polar plugs. Scale bar $=60 \mu \mathrm{m}$

The muscle scraping and digestion techniques allowed the observation of isolated eggs, which presented different maturation stages: (1) small, oval, pale eggs (Figs. 7 \& 8); (2) pale and embryonated (morula) eggs with protruding plugs (Fig. 9); (3) dark brown embryonated eggs containing a morula (Fig. 10); and (4) dark brown embryonated eggs with nematode larvae (Fig. 8). Small eggs $(\mathrm{n}=26)$ varied in length from 33.2 to $57.0 \mu \mathrm{m}(49.4 \pm 6.8$ [mean $\pm \mathrm{SD}$ ]; median: $51.3 \mu \mathrm{m})$ and in width from 26.1 to $37.7 \mu \mathrm{m}(31.4 \pm 3.6$; median: $31.8 \mu \mathrm{m})$. Larger dark brown eggs presented slightly protruding plugs. The length of these eggs $(\mathrm{n}=$ 50), including polar plugs, varied from 73.4 to $94.3 \mu \mathrm{m}$ $(83.9 \pm 4.0$; median: $88.2 \mu \mathrm{m})$, their width from 39.6 to $59.1 \mu \mathrm{m}(47.9 \pm 6.2$; median: $46.3 \mu \mathrm{m})$ and the opercu-

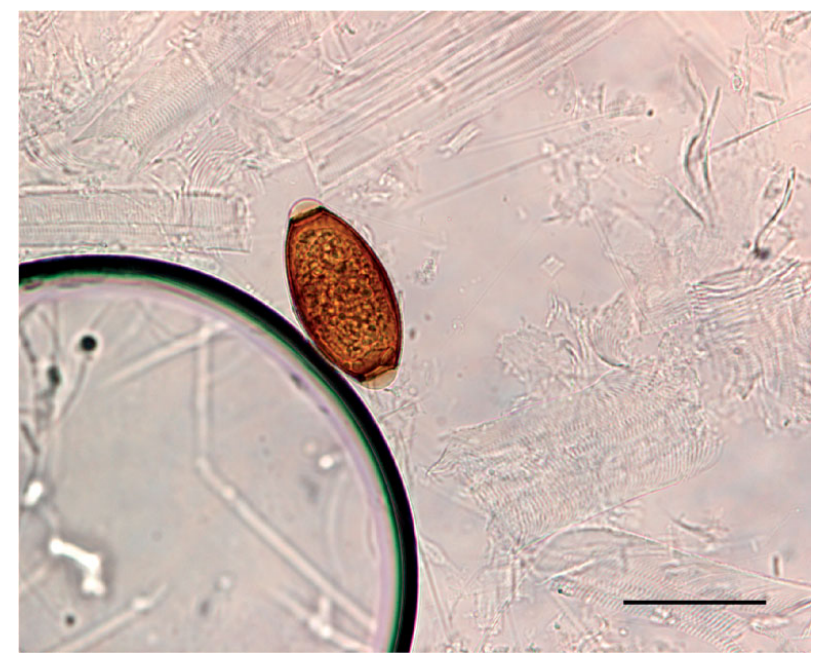

Fig. 10. Dark brown embryonated egg with morula. Scale bar $=60 \mu \mathrm{m}$

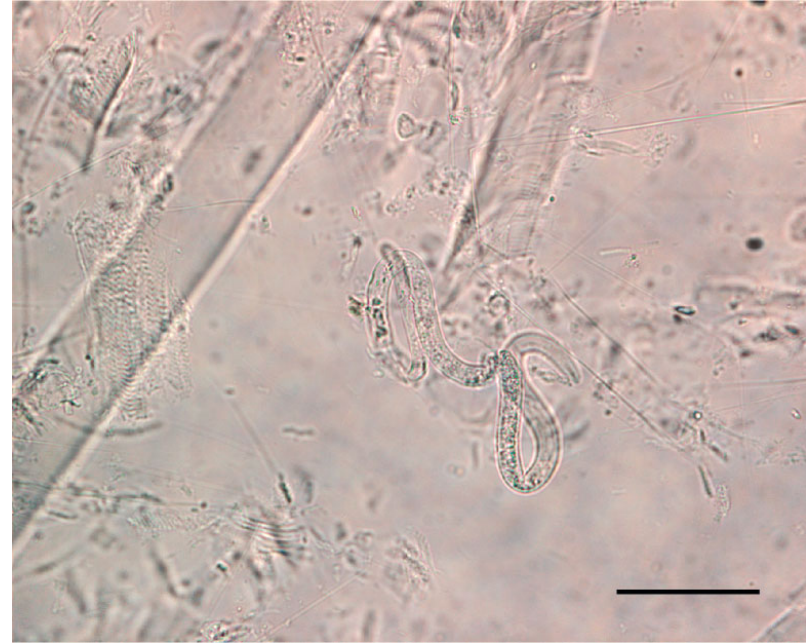

Fig. 11. Free nematode. Scale bar $=60 \mu \mathrm{m}$

lum from 13.6 to $22.3 \mu \mathrm{m}$ (17.6 \pm 1.7 ; median: $17.5 \mu \mathrm{m})$. The width of 13 larvae found inside eggs $(n=10)$ or free after muscle digestion $(\mathrm{n}=3$, Fig. 11) varied from 8.6 to $12.9 \mu \mathrm{m}(10.1 \pm 1.2$; median: $9.7 \mu \mathrm{m})$.

These bipolar eggs were typical of the Huffmanela nematode genus. According to the taxonomic key published by Moravec \& Fajer-Avila (2000), the morphology and distribution of the observed bipolar eggs were not compatible with any of the described Huffmanela species.

\section{DISCUSSION}

Huffmanela infection was first reported in sharks (MacCallum 1925, 1926 cited in Conboy \& Speare 2002), and so far 14 nominal species have been assigned to the genus (Justine 2005, Moravec et al. 2005, Carballo \& Navone 2007). These include one freshwater species, $H$. huffmani, and 13 from marine fishes. The features by which individual Huffmanela species are separated can be identified from the species keys provided by Moravec \& Fajer-Avila (2000), which were adapted from Moravec et al. (1998). The morphological structure and measurements of trichinelloid eggs, such as their length, width and surface structure (size and shape), as well as the host type and the infection's location within the host, are diagnostic characteristics used in Huffmanela identification.

In the present study, those Trisopterus luscus condemned as unfit for consumption presented muscle with unusual black spots, due to the presence of darkshelled trichinelloid embryonated eggs throughout the muscle tissue. The morphology of the observed eggs is 
in accordance with microscopic characteristics previously described by Moravec et al. (1998) as the genus Huffmanela. Due to the morphology and distribution of these eggs (Moravec et al. 1998, Moravec \& FajerAvila 2000), these cases are not compatible with any previously described Huffmanela species. Considering the observed egg morphology, T. luscus Linnaeus (Gadiformes: Gadidae) as host and the new distribution record, it is possible that these specimens represent a new, unidentified Huffmanela species.

So far, all but 3 species of Huffmanela - H. huffmani Moravec 1987, H. shikokuensis Moravec, Koudela, Ogawa \& Nagasawa 1998 and H. canadensis Moravec, Conboy \& Speare 2005, comprising histozoic fish parasites - are recognisable only on the basis of their egg morphology and biological characteristics as well as location of the eggs in the host's body and the type of host involved.

In the present study, no adult nematodes were observed in the infected fish via macroscopic examination. As previously reported by Moravec et al. (1998), we microscopically observed intracellular nematodes, although it was not clear if they were at larval or adult stages. The presence of intracellular parasites suggests the nematodes' affinity to trichinellids (Moravec et al. 2005). Moravec et al. (1998) suggest that adult nematodes, after the rupture of the infected muscle cells, migrate, copulate and lay eggs in the intercellular tissue. We also observed sectioned nematode specimens inside a lymphatic vessel of intestine submucosa and in a dermal lymphatic vessel, which may be compatible with adult nematodes of the genus Huffmanela. This fact could be related to adult nematode migration inside the infected fish; however, this is speculative and merits further investigation because the normal location of adult parasites in infected fish is as yet unknown.

The identification of Huffmanela sp. in a new host (Trisopterus luscus) and in a new location (the Atlantic Ocean) is consistent with the general opinion that these parasites are widely distributed, particularly in marine fishes. Although so far there have been no reports of Huffmanela in human tissues, one wonders

Editorial responsibility: David Marcogliese, Montreal, Quebec, Canada how often these infections may have been overlooked or misdiagnosed.

Acknowledgements. The authors thank L. Bento and F. Borges for their expert technical assistance.

\section{LITERATURE CITED}

Carballo MC, Navone GT (2007) A new Huffmanela species (Nematoda: Trichosomoididae), parasitizing atherinid fishes in north Patagonian Gulfs, Argentina. J Parasitol 93:377-382

> Conboy GA, Speare DJ (2002) Dermal nematoidosis in commercially captured rockfish (Sebastes spp.) from coastal British Columbia, Canada. J Comp Pathol 127:211-213

Gállego J, Riera C, Portús M (1993) Huffmanela sp. eggs (Nematoda: Trichosomoididae), as a human spurious parasite in a child from Barcelona (Spain). Folia Parasitol 40:208-210

Justine JL (2005) Huffmanela lata n. sp. (Nematoda: Trichosomoididae: Huffmanelinae) from the shark Carcharhinus amblyrhynchos (Elasmobranchii: Carcharhinidae) off New Caledonia. Syst Parasitol 61:181-184

Mendes M (2006) Huffmanela sp. (Nematoda: Trichosomoididae) parasita muscular da faneca-Trisopterus luscus (Linnaeus, 1758) - na Costa Portuguesa. MS thesis, Universidade Técnica de Lisboa (in Portuguese)

Moravec F, Fajer-Avila E (2000) Huffmanela mexicana n. sp. (Nematoda: Trichosomoididae) from the marine fish Sphoeroides annulatus in Mexico. J Parasitol 86:1229-1231

Moravec F, Garibaldi F (2000) Huffmanela paronai sp. n. (Nematoda: Trichosomoididae), a new parasite from the skin of swordfish Xiphius gladius in the Ligurian Sea (western Mediterranean). Folia Parasitol 47:309-313

Moravec F, Koudela B, Ogawa K, Nagasawa K (1998) Two new Huffmanela species, $H$. japonica n. sp. and $H$. shikokuensis n. sp. (Nematoda: Trichosomoididae), from marine fishes in Japan. J Parasitol 84:589-593

Moravec F, Conboy GA, Speare DJ (2005) The new trichosomoid from the skin of Sebastes spp. (Pisces) from British Columbia, Canada. J Parasitol 91:411-414

Park JH, Guk SM, Kim TY, Shin EH and others (2004) Clonorchis sinensis metacercarial infection in the pond smelt Hypomesus olidus and the minnow Zacco platypus collected from the Soyang and Daechung Lakes. Korean J Parasitol 42:41-44

Svetovidov AN (1986) Gadidae. In: Whitehead PJP, Bauchot ML, Hureau JC, Nielsen J, Tortonese E (eds) Fishes of the north-eastern Atlantic and Mediterranean (Mirapinnidae to Xiphidae), Vol 2. UNESCO, Paris, p 511-1007

Submitted: August 8, 2008; Accepted: February 16, 2009 Proofs received from author(s): April 6, 2009 